\title{
AN ACCOUNT OF THE JOURNAL OF HYGIENE, 1901-1950
}

\author{
By the late G. S. Graham-Smith, M.D., D.P.H., F.R.S.
}

Editor of the Journal, 1939-1950

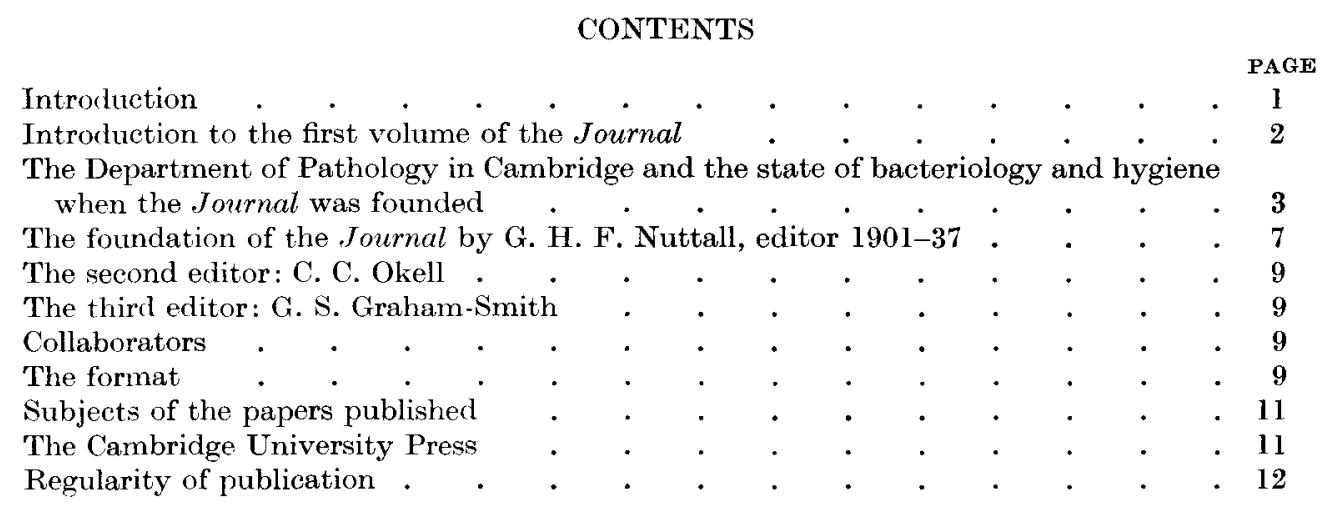

\section{INTRODUCTION}

(The manuscript notes from which the following Account of the Journal of Hygiene has been prepared for the press were left unfinished by Dr Graham-Smith at the time of his death on 30 August 1950. He intended that the Account should be published to mark the fiftieth year of the Journal's existence.

Dr Graham-Smith was probably associated with the Journal almost from its beginning, certainly from 1912. Nevertheless, his Account contains hardly any reference to himself. During his life he expressed a wish, which he stated again in his Will in the following words: ' . . by reason of the death of a large number of those with whom I was intimately associated and acquainted during the active part of my life I desire that there shall be no detailed obituary notice in the press....'

After careful consideration, it has been decided that Dr Graham-Smith's wish should be recorded but not complied with. Consequently, a short note about him is published in this number, immediately following his Account of the Journal, with which it may be read; for during its fifty years, the Journal was edited by its founder for thirty-eight years, and by Dr Graham-Smith for eleven years, Dr Okell's editorship having lasted for one year only.

The Account itself has been put together from Dr Graham-Smith's notes, and so far as is possible in his own words. The material as he left it included substantial transcriptions from his obituary notice of Nuttall (vol. 38, p. 129) and from H. J. Parish's obituary notice of Okell (vol. 39, p. 217). Much of the former has been retained because Dr Graham-Smith himself wrote it, and because it contains the quintessence of his regard for Nuttall and, better than anything another can now write, shows the vigour and excitement of the early years of the century and of the Journal. The note on Dr Okell has been shortened and modified 
to avoid repetition, and to show him as he was during his short time as editor, mentally vigorous and very courageous.

Much of Dr Graham-Smith's material consists of patiently compiled tabular analyses of matters relating to the Journal, such as the number of pages in every article, the dates of appearance of each number, and a classification of all articles by subject. These were evidently raw materials; without selection and rejection of much, the Account could not have been made coherent.

At the time of his death, he was also working on a History of the Department of Pathology in Cambridge; and it is not clear whether some of the material for the Account did not really belong to this other work. Selection has therefore been made from this material also. The material of the History of the Department of Pathology in Cambridge is being preserved in the University Library and the Department itself.-Editor.)

At the end of 1950, the Journal of Hygiene completed the fiftieth year of its publication. The Journal was founded by G. H. F. Nuttall in 1901, for reasons which he set out in the first volume, in an introduction appearing over the names of Nuttall himself, J. S. Haldane and Arthur Newsholme. This introduction may be quoted in its entirety, because it presents what is still the aim of the Journal:

\section{INTRODUCTION TO THE FIRST VOLUME OF THE JOURNAL}

'The Journal of Hygiene has been founded in order to meet a need which has long been felt for a journal devoted to the publication in the English language of original work in Hygiene. The results of such work in Great Britain, the Colonies and the United States, have hitherto for the most part appeared in journals devoted to General Medicine, Pathology, Physiology and Chemistry, or in official Reports or other publications not readily accessible for reference. The papers in question have, in consequence, frequently required to be unduly curtailed in the description and discussion of essential data, and have often escaped the notice of workers in the same subject, both in English-speaking and foreign countries. The numerous encouraging assurances of support received from those gentlemen who have kindly consented to collaborate with us have confirmed us in the opinion that the Journal of Hygiene will fulfil a definite purpose by serving as a focus to English-speaking investigators for works in Physics, Chemistry, Physiology, Pathology, Bacteriology, Parasitology and Epidemiology, in relation to Hygiene and Preventive Medicine.

'With a view to increasing the general usefulness of the Journal of Hygiene, we propose not to limit the contributions entirely to reports of original observations and experiments, but to accept and encourage discussions of administrative and practical questions, the importance of which is apt to be overlooked in scientific journals. We also contemplate the occasional publication of collective and critical reviews upon subjects of general interest in the domain of Hygiene, those papers to be accompanied by adequate bibliographical references. Although the list of collaborators (74 names, all well-known for their work in Hygiene or related subjects, were listed) is limited to those whose native tongue is English, we trust 
that foreign investigators will understand that their contributions will be welcome.

'We conclude this brief introduction with a letter expressing his approval and good wishes from a veteran leader in the Science of Hygiene, Sir John Simon.'

THE DEPARTMENT OF PATHOLOGY IN CAMBRIDGE, AND THE STATE OF

BACTERIOLOGY AND HYGIENE WHEN THE JOURNAL WAS FOUNDED

When Nuttall founded the Journal, he held the post of University Lecturer in Bacteriology and Preventive Medicine in the University of Cambridge, to which he had come in 1899 at the invitation of Prof. A. A. Kanthack and of Sir Clifford Allbutt, Regius Professor of Physic. The story of Nuttall's career has been told in the obituary notice published in the Journal in 1938.

From its beginning the Journal of Hygiene has been intimately associated with the Department of Pathology in Cambridge, to which in 1901 Nuttall belonged. It is to be hoped that some day the story of the part which the Department of Pathology in Cambridge played in the early development of preventive medicine and bacteriology and immunology in Britain will be told in full, for it is an impressive and interesting story.

Eight years before there was a Department of Pathology, the University of Cambridge gave the first university recognition in this country to preventive medicine by instituting the Diploma in Sanitary Science, the purpose of which was to test and certify the fitness of persons applying for various posts connected with preventive medicine, chiefly as medical officers of health. The first medical officer of health, Dr W. H. Duncan, had been appointed in Liverpool in 1847. Since that time, the number of such posts had been greatly increased throughout the country by successive acts of legislation.

Preventive medicine before 1876, the year in which the Diploma in Sanitary Science was instituted, was pre-bacteriological, for not until that year had any bacteria been shown to cause human disease. 1876 was indeed the year in which Robert Koch published in Cohn's Beiträge his classical article on 'Die Aetiologie der Milzbrandkrankheit begründet auf die Entwicklungsgeschichte des Bacillus anthracis', recording the first experimental production of an infection by inoculation of a pure culture.

At first, the University of Cambridge offered no teaching for its Diploma. In 1883, the year before the establishment of a Department of Pathology, H. Robinson, Assistant to the Professor of Chemistry, gave in the Chemical Laboratory 'a course of practical laboratory instruction in the subjects of Part I of the Examination', namely, in the principles of chemistry, especially in regard to public health as indicated in E. A. Parke's Manual of Practical Hygiene. The name of the Diploma was changed in 1887 to the Diploma in Public Health. It was discontinued in 1933.

By 1883 , bacteriology, chiefly on the Continent, had made great strides. Hansen had described the leprosy bacillus in 1874, and Neisser the gonococcus in 1879 . Pasteur had isolated the bacillus of fowl cholera in 1880, and Ogston in 1881 described the staphylococcus.

1881, three years before the establishment of a Chair and Department of Pathology in Cambridge, was the year in which Koch published his invention of 
solid culture media as a means of obtaining pure cultures of bacteria. In the following year, he announced his discovery of the tubercle bacillus, and Loeffler and Schütz described the bacillus of glanders. Other classical discoveries of pathogenic bacteria followed in rapid succession, so that, to quote Bulloch (1925), 'the decade 1876-1886 was the heyday of bacteriological aetiological discovery'.

In 1884, Charles Smart Roy, who, although primarily an experimental physiologist, had studied pleuropneumonia of cattle in the Argentine, and later went with C. S. Sherrington and J. J. Graham-Brown in 1885 to Spain to investigate a great cholera epidemic, was appointed the first Professor of Pathology in Cambridge. His department at first consisted of two very small rooms, one a mere closet, together with half another room, in Fawcett's building, and for the first two years his only help was one 'boy'. However, Roy quickly built up a vigorous school, through which passed a most impressive sequence of illustrious men, who were probably chiefly attracted by Roy's fame as an experimental physiologist. The list of them includes A. E. Wright, afterwards Sir Almroth Wright; H. D. Rolleston, afterwards Sir Humphry Rolleston; J. G. Adami, later professor of Pathology in McGill University; G. Cunningham; C. S. Sherrington, afterwards Sir Charles Sherrington; J. J. Graham-Brown; M. Nunn; W. B. Hardy, afterwards Sir William Hardy; E. Lloyd Jones; E. H. Hankin; W. Hunter; J. Lorrain Smith; A. A. Kanthack, who succeeded Roy as professor in 1892; F. F. Wesbrook; L. Cobbett; W. S. Lazarus-Barlow; J. W. W. Stephens; T. S. P. Strangeways; H. K. Anderson, later Sir Hugh Anderson; W. F. H. Blandford; H. E. Durham, who with Gruber discovered the agglutination reaction, and who introduced the 'Durham tube' into bacteriology; J. H. C. Dalton; Filchnic of Breslau; A. Gamgee; L. B. Keng; W. S. Melsome; W. Nicholls; and G. C. Phillips. Between 1884 and 1893 , of the sixty-four papers published from the department, some twenty-eight were on topics in bacteriology and immunity.

When Roy died in $\mathbf{1 8 9 7}$, he was succeeded by A. A. Kanthack, who had been deputizing for him since the autumn of 1895, while still Director of the Pathological Department of St Bartholomew's Hospital, which, at the time of his appointment to it in 1892, was the first whole-time pathological appointment in London. Unfortunately, Kanthack died at the early age of 36, having occupied the chair at Cambridge only for thirteen months. He was succeeded in February 1899 by G. Sims Woodhead, who was head of the Department during the first twenty years of the existence of the Journal of Hygiene. Woodhead is remembered to-day as the founder of the Journal of Pathology and Bacteriology, the first journal in this country to be devoted to these subjects. His own interests were largely bacteriological. He commenced his medical studies in Edinburgh and became a first-rate sprinter and forward in the University rugby football team. He graduated in 1878 and afterwards studied in Vienna. After graduation his time was almost wholly spent in the study of pathology. From 1881 to 1887 he was first assistant to Prof. W. S. Greenfield in Edinburgh and was the first exponent in Edinburgh of bacteriology. In 1885 he published papers on bacteria in water and on antiseptics. His Practical Pathology, published in 1883, was for thirty years a standard students' text-book. In 1885 he published, in collaboration with C. W. Hare, Practical 
Mycology, the first systematic book on bacteriology in the English language. In 1891 he produced Bacteria and their Products.

When the Research Laboratory of the Royal College of Physicians of Edinburgh was established in 1887 , it was the first laboratory in the country to be devoted to medical research, and Woodhead was appointed its first superintendent.

In 1890 he became the first Director of the laboratories of the Royal College of Physicians of London and the Royal College of Surgeons of England. Here he placed the manufacture of diphtheria antitoxin on a sound basis and carried out investigations for the Royal Commission on Tuberculosis, appointed in 1890.

When Woodhead went to Cambridge in 1899 , much of his time had to be spent in drawing up schemes for building a medical school and in begging for funds. Both the pathological and the surgical laboratories, especially the latter, were in a very bad condition, with roofs that leaked and dry rot which 'advancing from below, had reached the upper stories'. However, the Department of Pathology remained in its old building until 1904.

In 1901 Woodhead was appointed a member of the Royal Commission on Tuberculosis and worked energetically in connexion with it till the publication of its first Report in 1912.

In his first year at Cambridge, Woodhead's staff consisted of himself and the demonstrator, T. S. Pigg, who in 1903, changed his name to T. S. P. Strangeways; but in the same year, 1899, G. H. F. Nuttall came to Cambridge, and in 1900 was appointed University Lecturer in Bacteriology and Preventive Medicine. Woodhead's sympathetic interest was an important factor in the founding of the Journal.

In the years preceding Nuttall's arrival in Cambridge, interest in bacteriology and in immunity had been growing. In the two years 1897 and 1898 , twenty-six papers on bacteriological and immunological subjects were published from the Department; in the three years 1899 to 1901 , the number had increased to fortyfour. The decade 1886 to 1896 had been 'the first great period of immunological research'. The discovery of diphtheria toxin by Roux and Yersin, of antitoxic immunity by Behring and Kitasato, and Ehrlich's great contribution had stimulated the 'humoral' school of immunologists, while Metchnikoff's development of studies on phagocytosis headed the 'cellular' school. Nuttall himself had, in 1888, shown the bactericidal power of defibrinated blood.

Ehrlich in 1892 pointed out the difference between active and passive immunization. In 1894 Pfeiffer began his researches on bacteriolysis. Bordet began his experiments on haemolysis in 1895 , and in 1898 proved that haemolysis and bacteriolysis are similar in principle. The first systematic account of the agglutination reaction was published by Durham in 1896 and he published observations on 'group agglutination' in 1900-1, foreshadowing its application to the diagnosis and recognition of allied bacteria. R. Kraus, in 1897, discovered specific precipitation. Ehrlich gave a full account of his famous theory in 1900, and the complement fixation reaction was discovered by Bordet and Gengou in 1901. By the end of the nineteenth century, those problems which were susceptible of solution by the methods available before 1890 had, to a great extent, been solved and those which remained unanswered appeared to demand methods of attack along new lines. 
At the same time, 'it was clearly seen that the whole problem of immunity was of extreme complexity'.

Nuttall, soon after settling in Cambridge, began work on the precipitation reaction described by Kraus, and published several short papers on the subject. His chief work on the precipitation reaction, on which he was engaged for three years, was published in 1904 under the title of Blood Immunity and Blood Relationships. In this work, in which he was joined and assisted by G. S. Graham-Smith and by T. S. P. Strangeways, he was able to show, by the examination of nine hundred different sorts of blood, involving thousands of precipitation tests, that the serum reaction would confirm 'the usually accepted zoological classification and provided assistance to zoologists in disputed questions of animal relationship' (Dean, 1931).

Besides Woodhead, Strangeways and Nuttall, the following worked in the Department at the turn of the century: W. Myers (John Lucas Walker student, 1899-1901) worked mainly on precipitins and venoms, and went in 1900 on the yellow fever expedition of the Liverpool School of Tropical Medicine to Para in Brazil with Durham. Myers died there of the disease in 1901. E. S. St B. Sladen (J.L.W. student, 1899-1901) worked on the presence of tubercle bacilli in milk. In 1902 he was appointed a scientific investigator to the Royal Commission on Tuberculosis. H. C. Haslam (J.L.W. student 1901-2) devoted himself to the chemical study of proteins. L. Cobbett worked on the bacteriology and prevention of diphtheria until he was appointed a scientific investigator to the Royal Commission on Tuberculosis in 1902. H. E. Durham worked in the laboratory until he went to Brazil with Myers and again for a short period till he went to investigate beriberi in the Pacific in 1901. A. B. Greene worked on the artificial production of amyloid disease, and, for his thesis on this subject, was awarded the first Raymond Horton-Smith Prize in 1900. (G. S. Graham-Smith joined the Department in 1901, the year in which the Journal was founded.)

Teaching in bacteriology and preventive medicine was, by 1901, active in the Department of Pathology. Adami and Hankin had started a course of 'advanced lectures' in the bacteriology of disease and the biology of bacteria in 1890. Before this, Roy had given some lectures on 'general pollution', starting in 1884. This course had included some practical bacteriology. The course started by Adami and Hankin became the course for the D.P.H., in teaching for which many members of the Department gave a hand. Nuttall, in 1899, continued this course, and A. E. Shipley lectured on animal parasites in connexion with it.

In 1899, Woodhead organized, in addition to the course just mentioned, a special intensive course in the Long Vacation for students preparing for the final M.B. examination. 'This, which later became the 'bugs and drugs' course for the 2nd M.B., proved very popular. In some of the early years as many as seventy students attended it. Nuttall, Strangeways and Shipley took part in the teaching with Woodhead. The general activity and enthusiasm of the Department at the time of the foundation of the Journal is described in the obituary notice on Nuttall (vol. 38, p. 129) which may be quoted:

'His (Nuttall's) teaching was extraordinarily interesting and stimulating, for 
he not only spoke with great personal knowledge of his subject, but he knew nearly all the leading bacteriologists in America and Europe, told how their discoveries were made, described their successes and disappointments, methods, idiosyncrasies and disputes. During the practical work he was always present, first demonstrating the work that was to be done and afterwards going round from bench to bench to ascertain what help was required.... At tea, supplied at 4.30 under the large Sophora tree, familiar to all medical students till 1934 and the last relic of the Botanic Garden (1762-1852), on the site of which many laboratories now stand, he was on the friendliest terms with all, eagerly discussing any subject which arose and occasionally describing in glowing words, accompanied by apt gestures, some of his remarkable experiences in California and Mexico, or in the numerous laboratories he had visited or worked in....

'On fine evenings at about 8 o'clock Nuttall and Strangeways met the class under the tree and discoursed on the relation of pathology and bacteriology to practical medicine and public health, often citing their own experiments.

'In spite of many difficulties, they were very happy days for all and Nuttall often referred to them with enthusiasm in after years.'

(The foregoing account of the development of research and teaching in bacteriology and related subjects in Cambridge and elsewhere has been compiled from Dr Graham-Smith's material. His intention was to draw a picture of the background against which the Journal came into being; a background composed of a young and vigorously growing subject and of a brilliant and enthusiastic department. The description of the founding of the Journal given in the following section is taken chiefly from Dr Graham-Smith's obituary notice of Nuttall.)

\section{THE FOUNDATION OF THE JOURNAL BY G. H. F. NUTTALL, EDITOR 1901-37}

Before Nuttall came to Cambridge, he had acquired considerable experience in several branches of experimental research dealing with hygiene, and had become anxious to obtain some teaching post connected with the subject.

He had received the Boylston Prize from Harvard University for an essay entitled $A$ Contribution to the Study of Immunity, which incorporated his discovery of the bactericidal power of defibrinated blood. Other topics on which he had published papers included a method for estimating the number of tubercle bacilli in sputum; a method for inoculating media and animals with known numbers of bacteria; Bacillus aerogenes capsulatus (now called Clostridium welchii); the rearing of animals free from bacteria; and, perhaps most important of all, the rôle of arthropods as vectors of disease. Problems of preventive medicine and hygiene related to these and other topics were his chief interest.

In 1900 , considering that it was unlikely that the University would be able for a considerable time to establish a lectureship or any other post devoted to instruction and research in hygiene, or to provide the necessary accommodation, Nuttall thought he would be best able to forward the subject he had so much at heart by founding and editing a journal devoted to it. At that time there was no journal in England devoted to hygiene and few which would accept papers on the 
subject of more than a few pages in length. Short papers were occasionally accepted by the Journal of Pathology and Bacteriology, of which G. Sims Woodhead, who founded it in 1893, was the proprietor and sole editor. Woodhead warmly approved of Nuttall's proposal. Excellent and suitable papers by medical officers of health appeared from time to time in their local reports, but these had limited circulations and were therefore liable to be overlooked.

Before approaching the Cambridge University Press, Nuttall wished to obtain some information as to the probability of such a journal being a success and in 1900 communicated with the directors of most departments of pathology in the universities and important hospitals and of institutions engaged in similar work in this country, with the Medical Officer of the Local Government Board, and with many medical officers of health of the cities and large towns, asking if they thought the foundation of such a journal desirable, and, if so, whether they were of opinion that it would be likely to receive sufficient support in contributions and subscriptions. Nearly all approved of the project, but several pointed out that, though their libraries would probably subscribe to the journal, there might not be sufficient private subscriptions to bear, with the library subscriptions, the cost of the journal. He also had encouraging replies and promises of support from his friends and others in Canada and the United States. A list of these collaborators is given on page i of the first volume of the Journal.... After obtaining all the information he could, Nuttall, supported by A. E. Shipley, Woodhead and others, approached the Cambridge University Press with his proposal to found the Journal. His proposal was accepted and it was agreed to commence publication in 1901, with a limited guarantee from Nuttall and others and, in the early days, a grant from the Syndics of the Press. For the first few years the Journal was run at a slight loss, but as it came to stand on its own financial legs it began to be regarded by the Press as Nuttall's property, and up to the time of his death he received $£ 1456.15 s .0 d$. Since his death the Syndies have paid to his executor in respect of the sales of

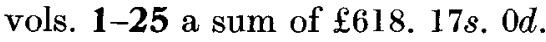

In his editorial work Nuttall displayed the same thoroughness as in his research. His two journals, the Journal of Hygiene and Parasitology, became models upon which the publications of several scientific societies were based. He spared no trouble in editing, going over almost every paper word by word, making emendations and suggestions and insisting on due credit being given to previous workers.... He considered that the duty of an editor does not consist only in assuring the regular appearance of the journal or in keeping the work published up to a certain standard, but is also educational. In fact, much of his time and energy were devoted to the correction and improvement of papers and to correspondence with contributors. He advised and helped young and inexperienced workers and in some cases rewrote their papers.

In 1936 Nuttall made up his mind to retire from the editorship of the Journal.

He died suddenly on 16 December 1937, with his enthusiasm and energy little impaired, on the eve of a dinner to be given by sixty colleagues in his honour on his retirement from his long and successful editorship of the Journal of Hygiene. 
THE SECOND EDITOR: C. C. OKELL

When Nuttall died, the editorship of the Journal passed to C. C. Okell. Okell at the time was living in Cambridge, whither he had retired suffering from a crippling arthritis which had compelled him to resign from the Chair of Bacteriology at University College Hospital. An account of Dr Okell's career, written by Dr H. J. Parish, was published in the Journal in 1939 (vol. 39, p. 217).

At the time of his appointment as editor, Okell was living the life of a semiinvalid. From his couch he maintained a constant literary activity, abstracting papers for the Bulletin of Hygiene, editing the Journal, and holding most stimulating discussions with younger bacteriologists who were frequent visitors at his home. Although hardly able to walk, he undertook a certain amount of teaching, chiefly in the form of discussions with the more advanced students. He maintained a keen intellectual activity, was always critical, interested and interesting, and he gave a powerful stimulus to those younger workers who were fortunate enough to have access to him. He died on 8 February 1939, having been editor for thirteen months.

\section{THE THIRD EDITOR: G. S. GRAHAM-SMITH}

In 1939, G. S. Graham-Smith, Reader in Preventive Medicine in the University of Cambridge, was appointed editor.

(This sentence is Dr Graham-Smith's only reference to his own editorship. He remained editor until his death on 30 August 1950, having held office during the difficult years of the 1939-45 war. He strove successfully to maintain the standard set by his predecessors.)

\section{COLLABORATORS}

From the first, Nuttall decided to ask a few of his colleagues to help him in deciding on the suitability of some of the papers submitted to him for publication, especially those on subjects with which he was not sufficiently acquainted to give a reliable judgement, or to suggest, if they were in doubt, to whom those papers should be sent for an opinion, and also to help him, if necessary, in editing such papers.

The names of these colleagues, which appear on the title page of each number under the heading 'in conjunction with' are given in Table 1, together with the years during which they served.

\section{THE FORMAT}

In the first format, which continued in use till the middle of vol. 43 (January 1944), the pages measured $10 \frac{1}{4} \times 7 \mathrm{in}$., and the area of the print, in a single column, $7 \frac{1}{2} \times 4 \frac{3}{4}$ in., giving approximately 500 words to the page. Each of the four numbers published quarterly, contained about 128 pages.

In vol. 38 (1938), presumably on Okell's advice, the numbers, instead of being published quarterly, began to be published bi-monthly. This method was continued till the end of vol. 44 (1946), after which quarterly publication was resumed.

In the middle of vol. 43 (January 1944) the format was changed in order to save paper during the second World War. The size of the page remained as before, 
Table 1. The names of those who worked ' in conjunction with' the editors
(1)
(2)
(3)
(4)
(5)
(6)
(7)
(8)
(9)

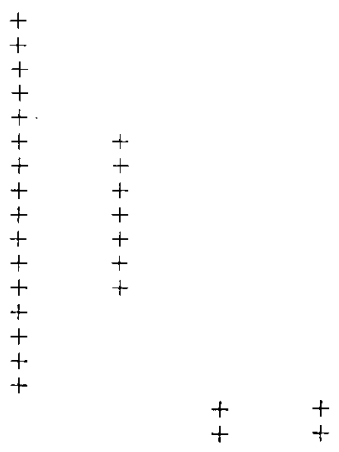

(1) Haldane, J. S. (1860-1936), M.D., F.R.S. (1897), Royal Medal, R.S. (1916), Copley Medal (1934). Lecturer in Physiology, University of Oxford: Reader in Physiology (1907-13), Professor in Mining Department, University of Birmingham.

(2) Newsholme, A. (1857-1943), M.D., F.R.C.P., K.C.B. Medical Officer of Health of Brighton; Principal Medical Officer, Local Government Board (1908).

(3) Martin, C. J. M.B., B.Sc., F.R.S. (1901), Royal Medal, R.S. (1923), Kt. Director of the Lister Institute of Preventive Medicine, London; Professor of Experimental Pathology in the University of London.

(4) Ledingham, J. C. G. (1875-1944), M.D., D.Sc., F.R.S. (1921), Kt., C.M.G. Bacteriologist-in-Chief, Lister Institute: Director of the Lister Institute and Professor of Bacteriology in the University of London.

(5) Graham-Smith, G. S. (1875-1950), M.D., F.R.S. (1919). University Lecturer in Hygiene, Cambridge; Reader in Preventive Medicine.

(6) Greenwood, MI. (1880-1949), M.R.C.S., F.R.S. (1928). Statistician, Lister Institute, London; Professor Emeritus of Epidemiology and Vital Statistics in the University of London.

(7) David Munro, M.B., K.C.B., C.I.E. Secretary, Industrial Health Research Board, Nedical Research Council.

(8) Topley, W. W. C. (1886-1944), M.D., M.Sc., F.R.C.P., F.R.S. (1930). Professor of Bacteriology and Immunology in the London Sehool of Hygiene and Tropical Medicine; Secretary of the Agricultural Research Council.

(9) Irwin, J. O., M.A., D.Sc., Sc.D., F.S.S. of the Medical Research Council's Statistical Research Unit, London School of Hygiene and Tropical Medicine.

(10) Wilson, G. S., M.D., F.R.C.P., D.P.H. Direetor, Public Health Laboratory Service (Medical Research Council, London).

The appointments held by each at the beginning and end of his association with the Joumal are given. 
but the type was smaller and arranged in two columns, and the margins reduced so that the area occupied by the print occupied $7 \frac{3}{4} \times 6 \frac{7}{8}$ in., giving approximately 1000 words to the page. This format was continued up to the end of vol. 47 (December 1949).

In vol. 48 (1950) another format was adopted closely resembling that of the present format of the Proceedings of the Royal Society, Series B. In this format the size of the page remains nearly the same as before, but the area of the single column of print is $8 \times 5 \frac{1}{8} \mathrm{in}$. and the type larger, giving about 500 words to the page.

Throughout the whole period of publication the format of the cover has remained the same.

\section{SLBJECTS OF THE PAPERS PUBLISHED}

In the fifty years, altogether 1777 papers were published in the Journal, not including five extra plague numbers and five plague supplements.

The subjects treated in these papers were as diverse as Nuttall's introduction to the first volume suggested that they would be. In the first seven years many papers on entomological and protozoal subjects appeared, but after the foundation by Nuttall of Parasitology in 1908, such papers seldom appeared in the Journal of Hygiene.

A full classification of the subjects of papers published would be too cumbrous; moreover, such a classification would give but an imperfect picture of the trends of interest in successive years, for sometimes a drop in the number of papers in any subject might indicate, not a drop in interest, but rather an increase therein to the point of the establishment of some new specialist journal likely to attract papers which would otherwise have come to the Journal of Hygiene.

Bacteriology and immunology have ranked high, but the range of subjects treated has been a very wide one.

Of special interest were the Plague Reports. The very important Reports on Plague Investigations in India, issued by the Advisory Committee appointed by the Secretary of State for India, the Royal Society and the Lister Institute, were published in the form of ten reports, divided into sections, which formed a consecutively numbered series. The first five reports were published as extra 'Plague numbers' in the Journal (1906-11). The sixth, seventh, eighth, ninth and tenth reports were issued as Plague Supplements, the last appearing in May 1917.

The editors have given hygiene a very wide definition and have adhered to Nuttall's original intention of accepting papers containing records of experimental results which, by their size, might have been less acceptable to journals less specifically devoted to hygiene. In spite of this, the great majority of papers have not been very long. The usual length of a paper has lain between three and thirteen pages, and very long papers have rarely appeared. The longest published had one hundred and eighteen pages.

\section{THE CAMBRIDGE UNIVERSITY PRESS}

On the death of Prof. Nuttall, the Cambridge University Press assumed full control of the Journal, which is printed and published at their expense. The copyright of the Journal belongs to the Syndies of the Press. 


\section{REGULARITY OF PUBLICATION}

In the period 1901-1914, publication was regular so that the volume numbers (1-14) corresponded with the year numbers. There followed a period of irregularity caused by wartime difficulties, but by 1930 the arrears had been made up, so that volume numbers and year numbers again corresponded. In the period 1931-1940, the full number of quarterly numbers was published in each of the first seven years and of six bi-monthly numbers in the last three years. The war of 1939-45 introduced new difficulties, and volume numbers began to lag behind year numbers, so that by 1950 the volume number had dropped behind by two.

The University Press has now been able to restore regularity of publication, but it is unlikely that volume number and year number will again correspond.

Under present circumstances, publication follows four months after receipt of the complete copy for a number; in other words, a paper should appear from four to eight months after its receipt by the editor, depending on the date of receipt and on the number of papers received. Allowing for a very small number of papers which have to be rejected as unsuitable for the Journal, the number of papers now being received each quarter about corresponds to the number required to make up one number of the Journal, so that in general there is no delay in publication on account of a 'waiting list'. 